\title{
Integrating tenure and governance into assessments of forest landscape restoration opportunities
}

\author{
Rebecca McLaina, Steven Lawry ${ }^{b}$, Manuel R. Guariguata ${ }^{c}$ and James Reed ${ }^{c}$
}

\section{Key messages}

- Many countries have adopted the Restoration Opportunities Assessment Methodology (ROAM) to guide the development of national and subnational restoration strategies.

- This study analyzes ROAM reports for eight countries to determine the extent to which tenure and related governance considerations were incorporated.

- Although all of the reports found that lack of rights or weak rights impeded efforts to scale up forest landscape restoration (FLR), none provided robust descriptions of the rights and responsibilities of individuals or communities to trees, forests or land under statutory or customary law.

- We propose a rights actualization framework as a diagnostic that can provide a solid foundation to identify policy reforms needed to address rights-related barriers to FLR implementation.

- FLR initiatives informed by a robust tenure rights assessment will enhance the likelihood of achieving their twin goals of improving ecological functionality and human well-being.

\section{Why tenure matters for forest landscape restoration (FLR)}

Guidance for forest landscape restoration (FLR) (e.g. Mansourian 2017; Stanturf et al. 2017) highlights the importance of enhancing community and smallholder tenure rights, tenure security and land governance systems in order to achieve environmental and social objectives. Because tenure and governance affect how FLR costs and benefits are distributed, they are likely to influence landholder and land user decisions about whether to invest in FLR practices (Cronkleton et al. 2017) The Restoration Opportunities Assessment Methodology (ROAM) developed by the International Union for the Conservation of Nature (IUCN) and World Resources

\footnotetext{
a CIFOR, Bogor, Indonesia; Portland State University, Institute for Sustainable Solutions

b CIFOR, Bogor, Indonesia

c CIFOR, Lima, Peru

d CIFOR, Bogor, Indonesia; Visiting Scholar, University of Cambridge Conservation Research Institute, The David Attenborough Building, Cambridge, CB2 3QZ, UK
}

Institute (WRI) is a process designed to inform national and subnational FLR planning strategies. Guidance is given in a handbook (IUCN/WRI 2014) and WRI's Restoration Diagnostic (WRI 2015), which encourage practitioners to incorporate tenure and governance considerations likely to affect FLR uptake. We assessed eight ROAM reports (Table 1) to see whether and how tenure and governance were incorporated into FLR opportunities assessment processes. Our analysis was guided by three questions:

- How and where do ROAM reports consider tenure rights and related governance issues?

- What tenure rights and related governance challenges are identified?

- What solutions are proposed for addressing tenure and governance challenges likely to affect FLR implementation?

Based on our findings, we provide recommendations for a tenure diagnostic that can be used as a complement to ROAM or other FLR assessments and an agenda aimed at enhancing the incorporation of tenure rights in FLR planning and programming. 


\section{Methods}

We identified ROAM reports using Google's search engine and through an examination of FLR-related websites (e.g. IUCN n.d., 2018). Our search was limited to reports published between 2011 and 2017, with 2011 being the date when the ROAM process was first piloted. Key words used included: forest restoration, forest landscape restoration, restoration opportunities assessment, ROAM, forest restoration diagnostic, and the French, Spanish and Portuguese translations for these keywords as used in the ROAM handbook series (IUCN 2019). We located six national and two subnational ROAM reports (Table 1), six in Africa and two in Latin America. Three of the assessments (Ghana, Guatemala and Rwanda) were pilots and were completed before the ROAM handbook was published. Because ROAM is still in the early phases of development, new components are likely to be incorporated into the process as planners gain experience in using it.

We combined insights from theory and empirical research on property rights and conservation investments, along with the success factors described in ROAM guidance documents, to develop criteria for assessing the tenure and governance coverage in the ROAM reports. The assessment criteria included tenure rights, tenure security, enforcement capacity, community engagement, policy and legal framework consistency, and multiscalar/multisectoral linkages (see Table 2)

\section{Overview of the ROAM process}

Although there is no standard ROAM format, the processes underlying the ROAM reports followed a broadly similar pattern. Each process began with a multistakeholder workshop to identify potential FLR interventions and assessment criteria. Next, a working group developed maps showing where each intervention type might be feasible. Field visits and subnational workshops elicited input from subnational and local stakeholders. Many countries incorporated one or more of the following analyses into their assessments: a cost-benefit analysis of restoration activities, a carbon sequestration value analysis, a restoration finance and sourcing assessment, and a policy and institutional analysis. After the analyses were completed, a national workshop was typically held to provide an expanded set of stakeholders the opportunity to discuss, validate and further refine the results. The core team then produced a final report summarizing the results and providing recommendations for national or subnational FLR plans or strategies.

\section{Treatment of tenure in ROAM reports}

ROAM participants have considerable leeway in how they interpret and apply guidance in the ROAM handbook and the WRI Restoration Diagnostic. We assessed the eight reports for
Table 1. Restoration Opportunity Assessment Methodology (ROAM) reports included in the study.

\begin{tabular}{lc}
\hline Country (assessment scale) & Date published \\
\hline Ethiopia (Amhara State) & 2017 \\
Ghana* (national) & 2011 \\
Ivory Coast (national) & 2016 \\
Malawi (national) & 2017 \\
Rwanda* (national) & 2014 \\
Uganda (national) & 2016 \\
Brazil (Pará State) & 2017 \\
Guatemala* (national) & 2014 \\
\hline
\end{tabular}

* Ghana, Guatemala and Rwanda were pilots

Table 2. Framework used to assess tenure and land governance coverage in Restoration Opportunity Assessment Methodology (ROAM) reports.

\begin{tabular}{ll}
\hline $\begin{array}{l}\text { Tenure/land } \\
\text { governance } \\
\text { dimension }\end{array}$ & $\begin{array}{l}\text { Indicator of tenure and land } \\
\text { governance coverage }\end{array}$ \\
\hline Tenure rights & $\begin{array}{l}\text { Describes rights and responsibilities } \\
\text { (statutory and customary) of } \\
\text { landholders and land users vis-à-vis } \\
\text { trees, forests, land and carbon, including } \\
\text { the rights of women, minorities and } \\
\text { disadvantaged groups } \\
\text { Describes community forestry or } \\
\text { comanagement arrangements }\end{array}$
\end{tabular}

Tenure security States whether land or resource tensions or conflicts are present and describes the nature of those tensions or conflicts

Enforcement Describes enforcement capacity capacity (community and government)

Community engagement

Policy and legal framework consistency

Describes community's level of engagement in FLR decision-making

Describes presence (or absence) of policy and legal framework inconsistencies likely to affect FLR interventions

Multiscale, multisectoral linkages
Describes whether and/or how actors at different scales and in different sectors coordinate policy making, planning, and FLR-related program implementation

their coverage of tenure and governance considerations using the rating system described in Table 3. Table 4 summarizes the overall coverage of tenure and land governance in the eight reports. As is the case for all written accounts of an event, the reports provide only a partial picture of what actually took place during the assessments. 
Table 3. Rating system used to assess tenure and governance coverage in the Restoration Opportunity Assessment Methodology (ROAM) reports.

\begin{tabular}{ll}
\hline $\begin{array}{l}\text { Rating of tenure and land } \\
\text { governance coverage }\end{array}$ & Rating criteria \\
\hline Very limited coverage & $\begin{array}{l}\text { Brief mention of tenure issues in one or more sections with little detail; does not include a } \\
\text { list or discussion of key laws or policies likely to affect tenure incentives for engaging in FLR; } \\
\text { does not describe statutory rights and responsibilities with respect to trees or land; does not } \\
\text { describe customary rights and responsibilities with respect to trees or land; information lacks } \\
\text { the specificity needed to identify appropriate policy reforms or accompanying measures }\end{array}$ \\
\hline Limited coverage & $\begin{array}{l}\text { Mentions tenure issues in one or more sections but provides limited detail; lists key laws or } \\
\text { policies that affect tenure incentives for engaging in FLR; provides a sense of which groups } \\
\text { have weak or no tenure rights; provides some information about rights and responsibilities } \\
\text { with respect to trees and land under statutory or customary law or both; information on tenure } \\
\text { lacks the specificity needed to identify appropriate policy reforms and accompanying measures }\end{array}$ \\
\hline Moderate but narrow coverage & $\begin{array}{l}\text { Provides a substantive discussion of tenure issues in one or more sections; lists or discusses } \\
\text { key laws or policies that affect tenure incentives for engaging in FLR; provides a sense of } \\
\text { which groups have weak or no tenure rights; provides some information about rights and } \\
\text { responsibilities with respect to trees and land under statutory or customary law or both; } \\
\text { information on one or more key tenure issues is sufficiently specific that it is possible to identify } \\
\text { appropriate policy reforms and accompanying measures }\end{array}$ \\
\hline
\end{tabular}

Table 4. Tenure coverage in the Restoration Opportunities Methodology (ROAM) reports.

\begin{tabular}{|c|c|c|c|c|c|c|}
\hline Country & $\begin{array}{l}\text { Overall } \\
\text { assessment } \\
\text { of tenure } \\
\text { coverage }\end{array}$ & $\begin{array}{l}\text { Tenure data } \\
\text { included in } \\
\text { geospatial } \\
\text { analysis }\end{array}$ & $\begin{array}{l}\text { Type of } \\
\text { cost- } \\
\text { benefit } \\
\text { analysis }\end{array}$ & $\begin{array}{l}\text { Included a } \\
\text { restoration } \\
\text { finance } \\
\text { analysis }\end{array}$ & $\begin{array}{l}\text { Included a carbon } \\
\text { values analysis }\end{array}$ & $\begin{array}{l}\text { Type of } \\
\text { policy and } \\
\text { institutional } \\
\text { analysis }\end{array}$ \\
\hline Rwanda & $\begin{array}{l}\text { Very limited } \\
\text { coverage }\end{array}$ & $\begin{array}{l}\text { Park and reserve } \\
\text { locations }\end{array}$ & Quantitative & Yes & $\begin{array}{l}\text { Briefly describes carbon } \\
\text { rights }\end{array}$ & $\begin{array}{l}\text { Restoration } \\
\text { Diagnostic }\end{array}$ \\
\hline Uganda & $\begin{array}{l}\text { Limited } \\
\text { coverage }\end{array}$ & $\begin{array}{l}\text { Park and reserve } \\
\text { locations }\end{array}$ & Quantitative & No & $\begin{array}{l}\text { Does not describe carbon } \\
\text { rights }\end{array}$ & $\begin{array}{l}\text { Restoration } \\
\text { Diagnostic }\end{array}$ \\
\hline Malawi & $\begin{array}{l}\text { Moderate } \\
\text { but narrow } \\
\text { coverage }\end{array}$ & Protected areas & Quantitative & Yes & $\begin{array}{l}\text { Included in financial } \\
\text { analysis in appendix; does } \\
\text { not mention carbon rights }\end{array}$ & $\begin{array}{l}\text { Restoration } \\
\text { Diagnostic }\end{array}$ \\
\hline $\begin{array}{l}\text { Ethiopia } \\
\text { (Amhara) }\end{array}$ & $\begin{array}{l}\text { Moderate } \\
\text { but narrow } \\
\text { coverage }\end{array}$ & Protected areas & Quantitative & No & $\begin{array}{l}\text { Does not describe carbon } \\
\text { rights }\end{array}$ & $\begin{array}{l}\text { Restoration } \\
\text { Diagnostic }\end{array}$ \\
\hline Ivory Coast & $\begin{array}{l}\text { Limited } \\
\text { coverage }\end{array}$ & $\begin{array}{l}\text { No tenure } \\
\text { variables included }\end{array}$ & Qualitative & No & $\begin{array}{l}\text { Does not describe carbon } \\
\text { rights }\end{array}$ & $\begin{array}{l}\text { List of laws and } \\
\text { policies }\end{array}$ \\
\hline Ghana & $\begin{array}{l}\text { Moderate } \\
\text { but narrow } \\
\text { coverage }\end{array}$ & $\begin{array}{l}\text { Forest reserves } \\
\text { and national park } \\
\text { boundaries }\end{array}$ & Qualitative & No & $\begin{array}{l}\text { Calls for carbon rights } \\
\text { legislation }\end{array}$ & $\begin{array}{l}\text { Narrative } \\
\text { discussion of } \\
\text { policy/legal } \\
\text { framework }\end{array}$ \\
\hline Brazil (Pará) & $\begin{array}{l}\text { Moderate } \\
\text { but narrow } \\
\text { coverage }\end{array}$ & $\begin{array}{l}\text { Indigenous } \\
\text { territories and } \\
\text { conservation } \\
\text { areas, Rural } \\
\text { Environmental } \\
\text { Registry parcels }\end{array}$ & Quantitative & $\begin{array}{l}\text { Not as a } \\
\text { separate } \\
\text { section within } \\
\text { the report but } \\
\text { discussed in } \\
\text { other sections }\end{array}$ & $\begin{array}{l}\text { Does not describe carbon } \\
\text { rights but identifies } \\
\text { payments for ecosystem } \\
\text { services as essential for } \\
\text { FLR success }\end{array}$ & $\begin{array}{l}\text { Restoration } \\
\text { Diagnostic }\end{array}$ \\
\hline Guatemala & $\begin{array}{l}\text { Moderate } \\
\text { but narrow } \\
\text { coverage }\end{array}$ & $\begin{array}{l}\text { Yes - but map } \\
\text { published } \\
\text { as separate } \\
\text { document }\end{array}$ & $\begin{array}{l}\text { Cost-benefit } \\
\text { analysis } \\
\text { published } \\
\text { as separate } \\
\text { document }\end{array}$ & $\begin{array}{l}\text { Not as a } \\
\text { separate } \\
\text { section within } \\
\text { the report but } \\
\text { discussed in } \\
\text { other sections }\end{array}$ & $\begin{array}{l}\text { Carbon rights not } \\
\text { mentioned in discussion } \\
\text { of rights }\end{array}$ & $\begin{array}{l}\text { Narrative } \\
\text { discussion of } \\
\text { policy/legal } \\
\text { framework }\end{array}$ \\
\hline
\end{tabular}


Geospatial analysis: All of the reports included a geospatial analysis through which potential FLR sites were identified. Protected area boundaries were the only tenure data layers included in all but one report. Brazil's Pará State report also incorporated data layers for Legal Reserve and Areas of Permanent Protection that had been registered in the Environmental Rural Registry.

Cost-benefit analysis: Seven reports included a cost-benefit analysis for FLR interventions. ${ }^{1}$ Five reports used a quantitative approach in which it was assumed that individuals or communities that planted or protected trees would have the right to harvest and sell the trees or their products. This assumption does not account for situations where individuals or communities do not have these rights. Additionally, the analyses do not appear to have included the transaction costs associated with obtaining harvesting or transportation permits. The Ghana and Ivory Coast reports used a qualitative approach for their cost-benefit analyses. Both reports included a list of items that would need to be resolved in order to implement FLR on different land categories, with the items in the list being considered costs. A list of expected benefits was also developed for each land category. Tenure and governance issues, such as migrant farmers lacking rights to trees and weak enforcement of tree-felling restrictions, were included among the costs.

Restoration finance: The reports from Rwanda, Malawi, Pará and Guatemala discussed restoration finance options. Emphasis was placed on describing existing and potential investment sources external to communities. The Rwanda, Malawi and Pará reports identified incentivizing smallholders to invest in restoration on their holdings as essential, with assistance to small and medium enterprises being the key support mechanism. Guatemala's report also emphasized the key role that community forest concession rights have played in incentivizing community members to harvest timber sustainably in protected areas. Malawi's report explored community-based financing as an option, with funds from village forest management committees mentioned as one possible source of funding.

Carbon value analyses: The Rwanda and Ghana reports provided brief discussions of carbon rights; the other reports were silent on the topic of carbon rights.

Policy and institutional analysis: All of the reports included a policy and institutional analysis. However, the degree to which details on tenure and governance considerations were provided varied greatly. Some reports merely listed laws related to FLR; others described the key provisions of relevant laws. Some reports included only summary statements of tenure issues, such as "insecure tenure " or "weak enforcement"; others described which segments of the population had insecure

1 A document including a cost-benefit analysis of FLR interventions was published for Guatemala in 2018 after our study was completed. The citation is: Julien Colomer, Alejandro A. Imbach, Leander Raes, Ursula Parrilla, Florian Reinhard, Manuela Fernandez, Melissa Allemant. 2018. Value for Money: Guatemala's Forest Landscape Restoration. Gland, Switzerland: IUCN. access to land (i.e. migrant farmers in Ghana, women in Malawi and Uganda), which institutions lacked capacity or authority to enforce forest laws, and which laws were difficult to enforce. None of the reports included a systematic description of the rights and responsibilities of individuals or communities to trees, forests or land under statutory or customary law. Pastoralists' rights and secondary user rights were not covered in any of the reports. Only the Uganda and Malawi reports mentioned gender differences in rights to trees and land.

Despite their limited coverage of tenure rights, the ROAM reports provided useful insights about the tenure challenges likely to be encountered when implementing FLR programs, as well as some solutions to those challenges. Weak enforcement, limited community involvement in forest decision-making and lack of coordination between sectors, actors and scales were the most common challenges identified in the reports. As a solution, the reports from African countries emphasized the need to recognize or devolve rights to traditional authorities, and to expand community participation in forest management both on and off forest reserves. Land registration of individually held lands, communally held lands or both was identified as a solution to tenure insecurity in all of the reports. Another common solution put forth was the expansion of rights to harvest trees and other forest products for commercial use as a way to increase incentives for investing in FLR.

\section{Recommendations for future FLR assessments}

We offer two sets of recommendations for future ROAM and similar FLR assessments. Both are provisional in light of our limited sample size and the focus on reports completed during ROAM's early years. One set of recommendations outlines the elements of what a tenure-responsive ROAM analysis might include. The other describes a tenure-responsive FLR agenda that draws on lessons from REDD+ and community forestry initiatives.

The ROAM handbook and Restoration Diagnostic provide a starting point for incorporating tenure and governance, but the data emerging from the use of these tools are too general to be useful for planning FLR interventions. We conclude that a diagnostic specific to tenure and that also incorporates governance and equity issues, offers a possible solution. We propose a rights actualization model (see Figure 1) as the foundation for a tenure diagnostic that can enable planners to identify geographic areas where tenure is likely to encourage or discourage the adoption of FLR interventions and what kinds of tenure and land governance reforms will be required to support restoration on a large scale. Actual rights, which von Benda-Beckmann and von Benda-Beckmann (2000) refer to as concretized rights, are those rights that a rights holder can exercise in practice. 


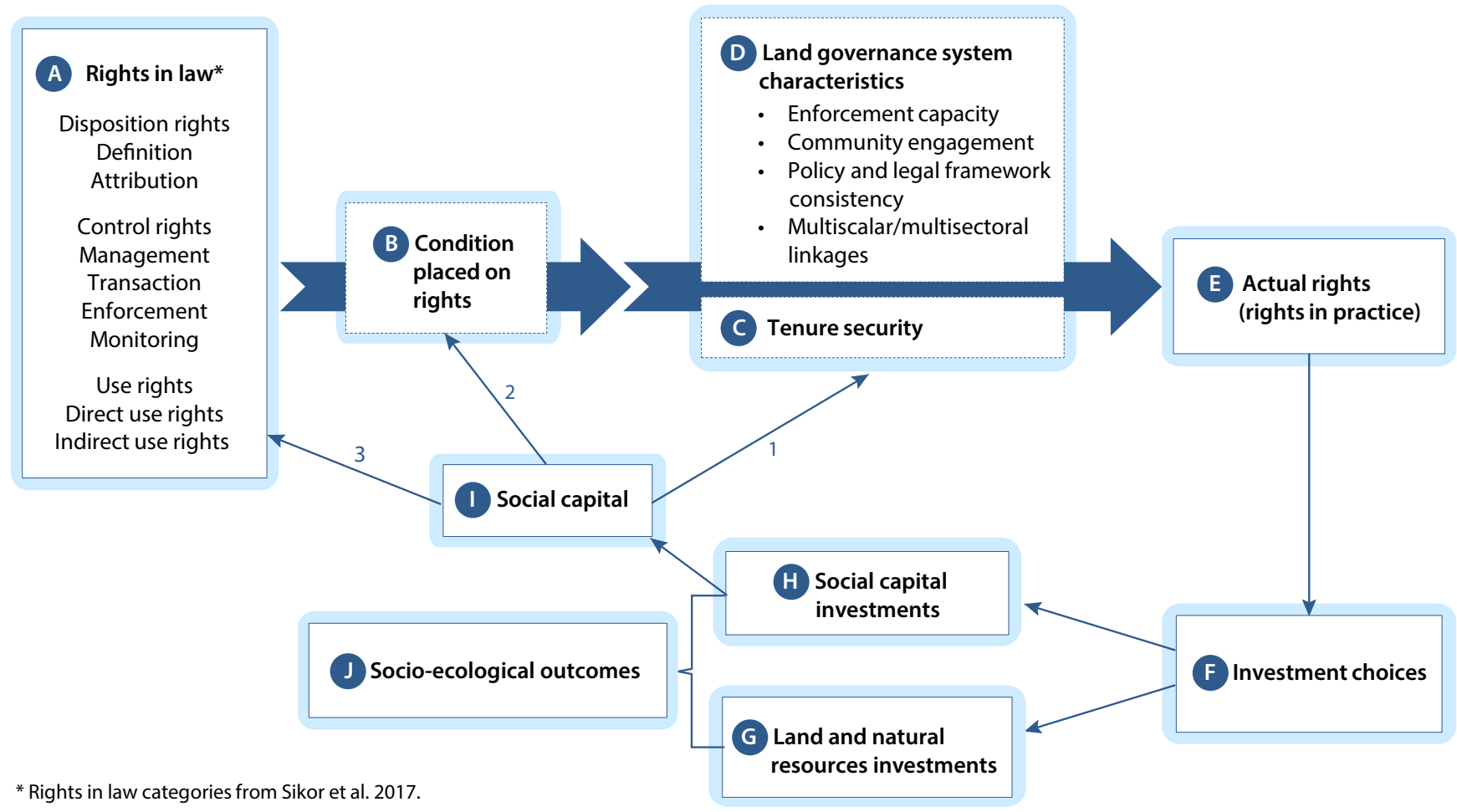

Figure 1. Rights actualization model for a restoration opportunities tenure diagnostic.

The starting point of the model (Element A) consists of rights in law, whether statutory or customary. These rights are typically conditioned in various ways (Element B). The conditioned rights are further conditioned by perceptions of tenure security and land governance conditions (Elements $C$ and $D$ ), resulting in actual rights (i.e. the rights that rights holders have in practice) (Element E). We posit that it is their actual rights, rather than rights in law, that incentivize people to make choices (Element F) about investments in improving land or natural resources $(G)$.

Drawing on research that shows that internal and crossscalar social networks are key factors contributing to successful forest rights devolution (Baynes et al. 2015), we propose that investments in social capital (Element $\mathrm{H})$ should be considered a type of FLR intervention. If unsatisfied with their actual rights, landholders may try to leverage their strengthened social capital (Element I) to influence the land governance system (e.g. improve enforcement capacity, expand community engagement, reconcile inconsistent policies) (Arrow 1) so that their actual rights align more closely with their rights in law. Alternatively, they may choose to use their strengthened social capital to change the conditions on their rights in law (Arrow 2) or the rights in law themselves (Arrow 3), thereby potentially affecting their actual rights. Ultimately, the land management and social capital investment choices that people make based on their actual rights are what lead to socio-ecological outcomes (Element J), and the success or failure of initiatives.
To operationalize the rights actualization model, at a minimum, a tenure and land governance analysis should answer two key questions:

1. Given the tenure and land governance arrangements in the target area, where and by whom are FLR interventions likely to be adopted on a broad scale?

2. Given the tenure and land governance arrangements in the target area, where and for whom will FLR interventions have a negative impact? In answering this question, secondary rights holders would be a particular concern, as would primary rights holders in areas with overlapping claims or where rights to land and pasturage, or land and trees, are separable.

Through answering these questions, the analysis should identify the tenure and land governance characteristics likely to affect the spatial and demographic patterns of FLR intervention adoption as well as their benefits and costs. Use of our proposed rights actualization model should facilitate the development of systematic descriptions of rights in practice as well as in law. A robust description of actual rights should enable the identification of FLR interventions appropriate for different types of rights. For example, persons who own their land would likely not be interested in planting trees for construction wood if the forestry code does not allow landowners to harvest their trees. However, they might agree to plant fruit trees if a viable market for the fruit exists. Those same landowners might be interested in joining a forest user association that advocates for legal reforms giving landholders the right to harvest trees they plant on their land. 


\section{Recommendations for a tenure- responsive FLR agenda}

A need also exists for a rights-enhanced paradigm for FLR program design and implementation. Three elements critical to a rights-enhanced approach are outlined below. Interventions associated with addressing all of these elements need to pay explicit attention to addressing gender and other social inequalities with regard to access to rights, benefits and social connectivity.

Rights and tenure security: Rights combined with tenure security provide the foundation of a rights-enhanced FLR. Two critical components - rights recognition/devolution and rights actualization - need to be addressed.

Rights recognition/devolution: In cases where informal customary rights already exist, securing formal recognition of those rights is recommended as a way to provide landholders with greater confidence that they will be able to influence and benefit from FLR activities, and to protect their rights from being eroded or taken away if FLR activities increase the value of the land or resources on it. Where informal customary rights do not exist or have been greatly weakened, policy interventions that support rights devolution are recommended.

Rights actualization: These interventions should focus on facilitating landholders' ability to exercise their rights in law, and reducing conditions on those rights that lead to tenure-related disincentives to restoration. Mechanisms for enhancing rights actualization include programs that improve accountability within land governance systems, provide accessible and affordable conflict resolution processes, enhance judicial competencies and build local-level enforcement and management capacities.

\section{Enhancing connectivity between scales, sectors and} social actors: The ROAM reports identify gaps in connectivity between and within scales of governance, as well as between sectors and different types of social actors, as impediments to FLR implementation. A key focal area for social connectivity enhancements is support for community-based user group networks with strong internal and external links to other stakeholders. Multistakeholder platforms have proved useful for building and strengthening links among actors within and between governance scales and sectors (Pinto et al. 2014). Brouwer et al. (2016) articulated a set of key principles for building effective multistakeholder partnerships, including embracing systemic change, transforming institutions, working with power, dealing with conflict, promoting collaborative leadership, fostering participatory learning and communicating effectively.

Program designs that generate widely shared benefits: The inequitable distribution of benefits emerged as a concern in many of the ROAM reports. Inequities in benefits distribution have also plagued REDD+ projects in spite of social safeguards, with indigenous peoples, women and poorer households tending to be left out (Larson et al. 2015; Ickowitz et al. 2017; Sarmiento Barletti and Larson 2017). FLR initiatives that fall outside the REDD+ umbrella are likely to experience similar outcomes, since many FLR interventions will have high opportunity costs for agriculture or may negatively impact secondary rights holders' access to resources. Providing strong forest-based benefits through devolving rights to harvest trees and forest products for commercial use can help offset the high opportunity costs of forests in relation to agricultural land uses.

\section{Conclusion}

The ROAM handbook and the Restoration Diagnostic identify the key elements needed to do a tenure and land governance analysis. However, they do not provide a framework that shows how those elements are connected to each other or to specific types of FLR interventions. By enabling planners to better understand those connections, our model should support FLR program designs that are tailored to the tenure and land governance context in which they are implemented. The limited coverage of tenure and land governance in the ROAM reports may also be related to the composition of the assessment teams, which appear to consist primarily of individuals with experience in natural science fields. Including at least one land tenure expert with field research experience on the core team is one possible solution; training core team members in how to do a tenure and land governance analysis is another option.

As with any model, ours simplifies reality. The elements and relationships we have depicted are influenced by other factors such as opportunity costs of investing in FLR, social and wealth status and distance from forest product markets, among others. How these factors interact with the elements of the model, how and when landholders or land users build social connections and activate them to influence land governance and tenure dimensions, and what the outcomes of the activation of social connections are on actual rights and investment choices are all areas in need of additional research. A logical next step is to test the model to see how well it works in practice at national and subnational scales.

The rights actualization model we propose has applicability beyond ROAM or other forest restoration assessments. The general principles should hold true for any planning context where tenure rights and security are at stake. It is, therefore, equally useful as a potential tool in other natural resource sectors, such as range management, agricultural development and fisheries management, where planners seek to affect land and resource management behavior. 


\section{Acknowledgments}

Funding from the CGIAR Research Program on Policies, Institutions and Markets (PIM) and the Center for International Forestry Research (CIFOR) supported this work. The authors thank Himal Baral and Ruth Meizen-Dick for their comments on earlier drafts of this Infobrief.

This Infobrief is adapted and condensed from Rebecca McLain, Steven Lawry, Manuel R. Guariguata, James Reed. 2018. Toward a tenure-responsive approach to forest landscape restoration: A proposed tenure diagnostic for assessing restoration opportunities. Land Use Policy. https://doi.org/10.1016/j. landusepol.2018.11.053

\section{References}

Baynes J, Herbohn J, Smith C, Fisher R and Bray D. 2015. Key factors which influence the success of community forestry in developing countries. Global Environmental Change Part A 35:226-38.

Brouwer H, Woodhill J, Hemmati M, Verhoosel K and van Vugt S. 2016. The MSP Guide, How to Design and Facilitate Multi-stakeholder Partnerships. Wageningen University and Research, CDI, and Rugby, UK: Practical Action Publishing, Wageningen. Accessed 10 September 2018. https://doi. org/10.3362/9781780446691

Cronkleton P, Artati Y, Baral H, Paudyal K, Banjane MR, Liu JJ, Tu TY, Putzel L, Birhane E and Kassa H. 2017. How do property rights reforms provide incentives for forest landscape restoration? Comparing evidence from Nepal, China and Ethiopia. International Forestry Review 19(54):8-23.

Ickowitz, A Sills, E and de Sassi C. 2017. Estimating smallholder opportunity costs of REDD+: a pantropical analysis from households to carbon and back. World Development 95:15-26.

[IUCN] International Union for Conservation of Nature. 2019. Restoration Opportunities Assessment Methodology (ROAM). IUCN. Accessed 16 January 2019. www.iucn.org/theme/ forests/our-work/forest-landscape-restoration/restorationopportunities-assessment-methodology-roam

[IUCN] International Union for Conservation of Nature. 2018. InfoFLR. IUCN. Accessed 16 January 2019. https://infoflr.org/

[IUCN] International Union for Conservation of Nature. n.d. Bonn Challenge. Washington, DC: IUCN. Accessed 16 January 2019. http://www.bonnchallenge.org/

[IUCN/WRI] International Union for Conservation of Nature/ World Resources Institute. 2014. A guide to the Restoration Opportunities Assessment Methodology (ROAM): Assessing forest landscape restoration opportunities at the national or sub-national level. Working Paper (Road-test edition). Gland, Switzerland: IUCN

Larson AM, Dokken T, Duchelle AE, Atmadja S, Resosudarmo IAP, Cronkleton P and Selaya G. 2015. The role of women in early REDD+ implementation: Lessons for future engagement. International Forestry Review 17(1):43-65.
Lawry S, Samii C, Hall R, Leopold A, Hornby D and Mtero F. 2016. The impact of land property rights interventions on investment and agricultural productivity in developing countries: A systematic review. Journal of Development Effectiveness 1:1-21.

Mansourian S. 2017. Governance and forest landscape restoration: A framework to support decision-making. Journal for Nature Conservation 37:21-30.

Pinto SR, Melo F, Tabarelli M, Padovesi A, Mesquita CA, de Mattos Scaramuzza CA, Castro P, Carrascosa H, Calmon M, Rodrigues R, César RG and Brancalion PHS. 2014. Governing and delivering a biome-wide restoration initiative: The case of Atlantic Forest Restoration Pact in Brazil. Forests 5(9):2212-29.

Sarmiento Barletti JP, Larson A. 2017. Rights abuse allegations and REDD+: A review and proposal for moving forward. CIFOR Infobrief no. 190. Bogor, Indonesia: Center for International Forestry Research (CIFOR). https://doi. org/10.17528/cifor/006630

Sikor T, He J and Lestrelin G. 2017. Property rights regimes and natural resources: A conceptual analysis revisited. World Development 93:337-49.

Stanturf J, Mansourian S and Kleine M, eds. 2017. Implementing Forest Landscape Restoration, a Practitioner's Guide. Vienna, Austria: International Union of Forest Research Organizations. von Benda-Beckmann F. and von Benda-Beckmann K. 2000. Gender and the multiple contingencies of water rights in Nepal. In: Pradhan R, von Benda-Beckmann F and von Benda-Beckmann K, eds. Water, Land and Law: Changing Rights to Land and Water in Nepal. Kathmandu/Wageningen/ Rotterdam: Legal Research and Development Forum (FREEDEAL)/Wageningen Agricultural University (WAU)/ Erasmus University Rotterdam (EUR). 17-38.

[WRI] World Resources Institute. 2015. The Restoration Diagnostic: A Method for Developing Forest Landscape Restoration Strategies by Rapidly Assessing the Status of Key Success Factors. Washington, DC: World Resources Institute.

\section{Appendix}

\section{Restoration Opportunity Assessment Methodology reports}

[CERGIS/WRI/IUCN] Centre for Remote Sensing and Geographic Information Services/World Resources Institute/International Union for Conservation of Nature and South Dakota State University. 2011. Assessment of Forest Landscape Restoration Opportunities in Ghana. Final Report. PROFOR. No publication location provided. Accessed 9 September 2018. https:// www.profor.info/sites/profor.info/files/Ghana\%20FLR\%20 PROFOR\%20final\%20report\%2029\%20September_0.pdf

Diederichsen, A., Gatti, G., Nunes, S., and Pinot, A. 2017.

Diagnóstico dos Fatores Chave de Sucesso para a Restauração da Paisagem Florestal. Município de Paragominas e Estado do Pará Componente da Metodologia de Avaliação de Oportunidades de Restauração (ROAM). 
Belém, PA: Instituo do Homem e Meio Ambiente da Amazônia (Imazon); Curitiba: Conserve Brasil. Accessed 17 January 2019.

Instituto Nacional de Bosques, Programa Forestal Nacional and Unión Internacional para la Conservación de la Naturaleza. 2014. Análisis del marco normativo y regulatorio, mapeo de iniciativas y diagnóstico de la situación de la restauración del paisaje forestal en Guatemala. Commissioned for: Mesa Nacional de Restauración del Paisaje Forestal: Guatemala. Unpublished document. On file with author.

[IUCN] International Union for Conservation of Nature. 2016. Opportunités de restauration des forêts et paysages dégradés en Côte d'Ivoire. Rapport Final. Ouagadougou, Burkina Faso: IUCN. Accessed 9 September 2018. https://www.iucn.org/ sites/dev/files/content/documents/opportunites_de_ restauration_des_forets_et_paysages_degrades_en_cote_ divoire.pdf

Nunes S, Gatti G, Diederichsen A, Silva D and Pinto A. 2017. Oportunidades para restauração florestal no Estado do Pará. Belém, Brazil: Instituo do Homem e Meio Ambiente da Amazônia (Imazon). Accessed 9 September 2018. https://imazon.org.br/PDFimazon/Portugues/livros/ Oportunidade\%20Restauracao\%20Florestal\%20Para.pdf Republic of Malawi, Ministry of Natural Resources, Energy and Mining. 2017. Forest landscape restoration opportunities assessment for Malawi. National Forest Landscape Restoration Assessment (Malawi). Blantyre, Malawi: Centre for Environmental Policy and Advocacy (CEPA). Accessed 9 September 2018. https://cepa.rmportal.net/Library/inbox/ forest-landscape-restoration-opportunities-assessment-formalawi/view

Republic of Rwanda, Ministry of Natural Resources. 2014. Forest Landscape Restoration Opportunity Assessment for Rwanda. Nairobi, Kenya: MINIRENA (Rwanda), International Union for Conservation of Nature (IUCN), World Resources Institute (WRI). Accessed 9 September 2018. https://www. iucn.org/content/forest-landscape-restoration-opportunityassessment-rwanda

Republic of Uganda, Ministry of Water and Environment and [IUCN] International Union for Conservation of Nature. 2016. Forest Landscape Restoration Opportunity Assessment for Uganda. Kampala, Uganda: Ministry of Water and Environment. Accessed 9 September 2018. https://www. iucn.org/content/forest-landscape-restoration-opportunityassessment-uganda

Silva, D and Nunes, S. 2017. Avaliação e modelagem econômica da restauração florestal no Estado do Pará. Belém, Brazil: Instituo do Homem e Meio Ambiente da Amazônia (Imazon). Accessed 9 September 2018. http://imazon.org. br/publicacoes/avaliacao-e-modelagem-economica-darestauracao-florestal-no-estado-do-para/ 